\title{
31. COCCOLITH STRATIGRAPHY LEG 7, DEEP SEA DRILLING PROJECT
}

David Bukry ${ }^{1}$, U. S. Geological Survey, La Jolla, California

Leg 7 of the Deep Sea Drilling Project from Guam to Hawaii, August-October 1969, recovered 148 cores at seven drilling sites (Figure 1). Light-microscope techniques were used to examine 230 samples from these cores for coccoliths. Some coccolith species in selected samples from each drilling site, listed by biostratigraphic zone, follow a summary of the coccolith stratigraphy at each site. The coccolith zones used in this report are based on the tentative ones described by Bukry and Bramlette (1970) in the report on Leg 3. Recent modifications to that system of zones are presented and applied in this report. Helpful discussions on coccolith stratigraphy with M. N. Bramlette of Scripps Institution of Oceanography during study of Leg 7 cores are gratefully acknowledged.

The term coccoliths refers to any calcified skeletal elements produced by the golden-brown nannoplankton algae Coccolithophyceae. For purposes of discussion, discoasters and other incertae sedis genera of calcareous nannofossils are sometimes referred to in a general inclusive sense as coccoliths. ${ }^{1}$ Publication authorized by the Director, U. S. Geological
Survey.
Species considered in this report are listed in Table 1.

\section{TABLE 1}

Coccolith Species Considered In This Report

Bramletteius serraculoides Gartner

Campylosphaera dela (Bramlette and Sullivan)

Catinaster calyculus Martini and Bramlette

Catinaster sp. cf. C. calyculus Martini and Bramlette Catinaster coalitus Martini and Bramlette

Ceratolithus cristatus Kamptner

Ceratolithus rugosus Bukry and Bramlette

Ceratolithus sp cf. C. rugosus Bukry and Bramlette

Ceratolithus tricorniculatus Gartner

Chiasmolithus grandis (Bramlette and Riedel)

Coccolithus bisectus (Hay, Mohler, and Wade) of Bramlette and Wilcoxon

Coccolithus sp. aff. C. bisectus (Hay, Mohler, and Wade) of Bramlette and Wilcoxon

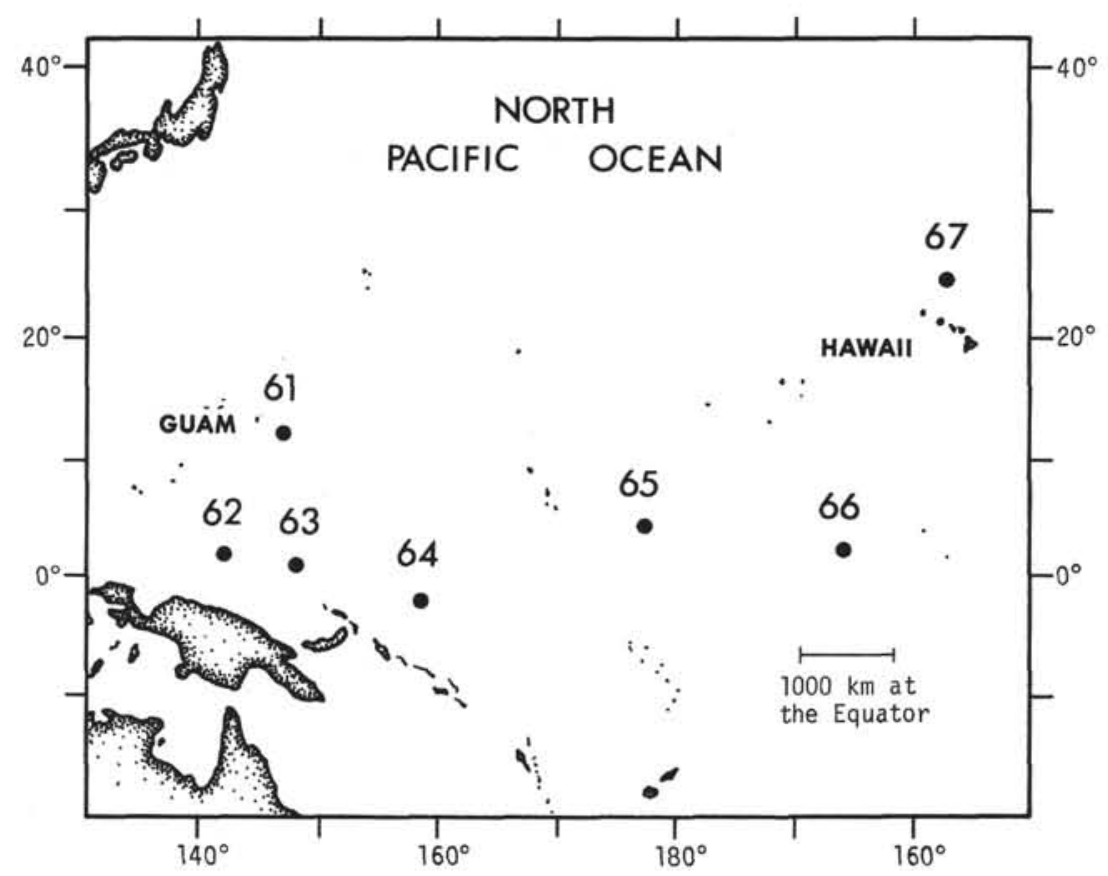

Figure 1. Location of drilling sites, Leg 7, Deep Sea Drilling Project 
TABLE 1 - Continued

Coccolithus doronicoides Black and Barnes

Coccolithus eopelagicus (Bramlette and Riedel)

Coccolithus pataecus Gartner

Coccolithus pelagicus (Wallich)

Coccolithus sp. cf. C. pseudogammation Bouché

Cyclococcolithus formosus Kamptner

Cyclococcolithus inversus (Deflandre)

Cyclococcolithus leptoporus (Murray and Blackman)

Cyclococcolithus macintyrei Bukry and Bramlette

Cyclococcolithus neogammation Bramlette and Wilcoxon

Cyclococcolithus reticulatus Gartner and Smith

Discoaster asymmetricus Gartner

Discoaster sp. cf. D. aulakos Gartner

Discoaster barbadiensis Tan

Discoaster bollii Martini and Bramlette

Discoaster brouweri Tan

Discoaster brouweri rutellus Gartner

Discoaster calcaris Gartner

Discoaster challengeri Bramlette and Riedel

Discoaster deflandrei Bramlette and Riedel

Discoaster sp. cf. D. deflandrei Bramlette and Riedel

Discoaster dilatus Hay

Discoaster sp. cf. D. dilatus Hay

Discoaster druggi Bramlette and Wilcoxon

Discoaster sp. cf. druggi Bramlette and Wilcoxon

Discoaster exilis Martini and Bramlette

Discoaster hamatus Martini and Bramlette

Discoaster kugleri Martini and Bramlette

Discoaster neohamatus Bukry and Bramlette

Discoaster pentaradiatus Tan

Discoaster perclarus Hay

Discoaster perplexus Bramlette and Riedel

Discoaster quinqueramus Gartner

Discoaster saipanensis Bramlette and Riedel

Discoaster surculus Martini and Bramlette

Discoaster tani nodifer Bramlette and Riedel

Discoaster tani tani Bramlette and Riedel

Discoaster variabilis Martini and Bramlette

Discoaster sp. aff. variabilis Martini and Bramlette

Discolithina japonica Takayama
TABLE 1 - Continued

Emiliania annula (Cohen) n. comb.

basionym:

Coccolithites annulus Cohen, 1964. Micropaleontology. 10 (2), p. 237, pl. 3, figs. 1a-1e.

Emiliania huxleyi (Lohmann)

Gephyrocapsa caribbeanica Boudreaux and Hay

Gephyrocapsa oceanica Kamptner

Helicopontosphaera ampliaperta (Bramlette and Wilcoxon)

Helicopontosphaera compacta (Bramlette and basionym: Wilcoxon) n. comb.

Helicosphaera compacta Bramlette and Wilcoxon, 1967. Tulane Stud. Geol. 5 (3), p. 105, pl. 6, figs. 5-8.

Helicopontosphaera sp. cf. H. compacta (Bramlette and Wilcoxon)

Helicopontosphaera kamptneri Hay and Mohler Helicopontosphaera reticulata (Bramlette and Wilcoxon) Helicopontosphaera sellii Bukry and Bramlette Isthmolithus recurvus Deflandre

Leptodiscus larvalis Bukry and Bramlette Oolithotus antillarum (Cohen)

Orthorhabdus serratus Bramlette and Wilcoxon

Pontosphaera vadosa Hay, Mohler, and Wade

Reticulofenestra pseudoumbilica (Gartner)

Reticulofenestra umbilica (Levin)

Scyphosphaera sp. cf. S. apsteinii Lohmann

Scyphosphaera pulcherrima Deflandre

Scyphosphaera recurvata Deflandre

Sphenolithus abies Deflandre

Sphenolithus belemnos Bramlette and Wilcoxon

Sphenolithus sp. aff. S. belemnos Bramlette and Wilcoxon

Sphenolithus ciperoensis Bramlette and Wilcoxon

Sphenolithus distentus (Martini)

Sphenolithus heteromorphus Deflandre

Sphenolithus moriformis (Brönnimann and Stradner)

Sphenolithus neoabies Bukry and Bramlette

Sphenolithus predistentus Bramlette and Wilcoxon

Sphenolithus pseudoradians Bramlette and Wilcoxon

Sphenolithus radians Deflandre

Triquetrorhabdulus carinatus Martini

Triquetrorhabdulus sp. cf. carinatus Martini

Triquetrorhabdulus rugosus Bramlette and Wilcoxon Triquetrorhabdulus inversus Bukry and Bramlette Zygrhablithus crassus (Locker) 


\section{COCCOLITH ZONATION}

Recent improvements to the Tertiary coccolith zonation system (Gartner 1969, Bukry and Bramlette 1970) are included in the recognition of zones for Leg 7. With each succeeding leg of the Deep Sea Drilling Project, the stratigraphic ranges of certain coccolith species used in zonation are confirmed and others extended; thus, the concept of any zone can be open to reinterpretation. However, certain guiding principles of the American Commission on Stratigraphic Nomenclature (1961, p. 655) concerning zones are unaffected by such reinterpretation: "A biostratigraphic unit is a body of rock strata characterized by its content of fossils contemporaneous with the deposition of the strata" and reworked fossils "are not relevant in defining a biostratigraphic unit." Further, in defining a zone as the "general basic unit in biostratigraphic classification" it is considered that, "a biostratigraphic zone is defined solely by the fossils it contains, without reference to lithology, inferred environment, or concepts of time."

For zones to be most widely and consistently recognized, relative abundances and first and last occurrences of the spectrum of species present in a natural zonal assemblage should take precedence over the range of any given single species. In this way, anomalies in species distribution caused by reworking, dissolution and geographic exclusion will not have a debilitating effect on the usefulness of zones.

Zonal boundaries recognized solely on the basis of the last occurrence of single species are considered least useful because of the possibility of reworking of coccoliths. Boundaries based on the first occurrences of single species do avoid the problem of reworking, but still are greatly subject to randomness owing to ecology and preservation. The type of stratigraphic zonation that is considered most useful for coccoliths is that advocated by $\mathrm{M}$. N. Bramlette, which utilizes the specific character of an assemblage bounded by closely spaced multiple first and last occurrences. In this scheme, the character of the whole assemblage is not dependent on the presence or absence of any single person.

Obviously, precise definitions of such multiple concurrent range zones are more lengthy, and seemingly less precise than those based on simple first or last occurrences of a single species; but, practical application of zonation to more than one area requires use of the nature of the whole assemblage, along with the firstlast occurrences of key species.

The sequences of thirty Cenozoic coccolith zones and subzones in the following discussion represent sequences of events in coccolithophore populations during a period of some 46 million years, as determined by radiometric and paleomagnetic evidence (Berggren, 1969; Heirtzler and others, 1968). While biostratigraphic zones are defined on the basis of fossil content, the ultimate goal of the process is an ordering and correlation of historical events.

Particularly important to the development of an effective biostratigraphic zonation by coccoliths is the statement that reworked fossils should not play a part in defining biostratigraphic units. Owing to their small size ( 1 to 50 microns, average 7 microns), coccoliths may be reworked into post-contemporaneous strata. Actual "last occurrences" can represent post-extinction occurrences. As the definition for the top of a zone, the last occurrence of a single species may range abnormally, owing to local and regional reworking and therefore be irrelevant to defining a biostratigraphic unit. If the general succession of first and last occurrences of a group in time and space is known, it is possible to recognize the exotic members in a given assemblage of fossils and filter them from the information used to assign the indigenous assemblage to a zone. For example, Pleistocene and Holocene sediment of the Mississippi cone in the Gulf of Mexico contains many Cretaceous coccoliths clearly reworked from the drainage area of the Mississippi and other Gulf Coast rivers, as they co-occur with coccoliths that first appeared worldwide in sediment considered Pleistocene. Far from easy, however, is the case where assemblages of contiguous zones are differentiated by changes in only a very few taxa. It is here that imprecision involved in a zone based on the last occurrence of a single species is greatest. The uppermost coccolith zone assigned to the Pliocene, the Discoaster brouweri Zone, may be defined at the top by the last occurrence of that species (Hay and others, 1967; Gartner, 1969 ) or by a combination of changes in the coccolith assemblages (Bukry and Bramlette, 1970). The base of the immediately succeeding zone may be defined by the same last occurrence of $D$. brouweri. Any reworked specimen of $D$. brouweri will extend or reduce the zones thus defined, and could lead to miscorrelation, unless other species in the assemblage are considered.

If, for example, the single species $D$. brouweri were not present because of preservational or geographic factors, a single-species zone defined on this species would be indistinguishable from adjacent zones. For zonal determinations, however, a group of coccoliths is examined, not a single species, and recognition of the relative stratigraphic order of changes of the assemblage rather than of the presence of any single species is more dependable for recognition of zones. Thus, the Discoaster brouweri Zone of Bukry and Bramlette is defined as having $D$. brouweri and $D$. pentaradiatus as the dominant discoasters in the zone. The top of the zone is recognized by an abrupt reduction in the abundance of $D$. brouweri and D. pentaradiatus, Cyclococcolithus macintyrei and Ceratolithus rugosus. The base of the zone is marked by the upper limit of Reticulofenestra pseudoumbilica, Sphenolithus abies and Sphenolithus 
neoabies. Coccolithus doronicoides is abundant throughout the zone. In the upper part of the zone, three-rayed forms of $D$. brouweri may be especially common.

Coccolith samples are studied as vast assemblages. Smear slides prepared for light-microscope study contain tens of thousands of specimens. Thus a correct determination of whether a particular species is present or absent depends on many factors: its frequency in the particular sample, the time available to the paleontologist, the distinctiveness of the particular species with respect to other forms within the assemblage. The first occurrence or the last occurrence of a species may not represent its period of maximum abundance. Use of a single species at a low abundance level to define zonal limits puts a premium on time-consuming search, and can easily lead to inconsistency in determinations.

Another problem is the possibility that a presumed marker species might prove to be a rate variant of a parent stock that may appear recurrently at various horizons in small numbers. In cores from Leg 7, for example, Discoaster asymmetricus is sparsely present in samples containing assemblages which are late Miocene and early Pliocene in age (Hole 62.1, Cores 13, 17 and 23). As this species is morphologically related to $D$. brouweri (the parent stock), it probably represents a recurrent variant in the late Miocene assemblages. Thus the base of a zone in the Pliocene defined by the first occurrence of this species could be determined to occur within other preceding zones. However, the general stratigraphic concept of a zone based on D. asymmetricus is useful when considered as a subzone that is based on the assemblage of associated coccoliths and on the increased abundance of $D$. asymmetricus in upper-lower Pliocene.

The identification of tentative zones and subzones that follows is developed from zonal studies of M. N. Bramlette and co-workers, W. W. Hay and co-workers, Stefan Gartner, and from this writer's light-microscope work on oceanic sediment cored by the Deep Sea Drilling Project, Leg 1 through Leg 7. This zonation is intended to serve as a practical framework based on key species and the nature of the associated coccolith assemblages. The relationships of the multiple concurrent range zones described here are indicated in Table 2.

\section{DESCRIPTIONS OF TENTATIVE MULTIPLE CONCURRENT RANGE ZONES}

\section{Emiliania huxleyi Zone}

This zone is characterized by the overwhelming dominance of Emiliania huxleyi. Whereas the top of the zone is the present water-sediment interface wherever $E$. huxleyi is present in sediments as a dominant coccolith species, defining the base of the zone is more difficult. Owing to the small size of E. huxleyi (2 to 3 microns), specific identification is not directly possible by light microscope. However, if the coccolith assemblage is dominated by these small coccoliths, which are faintly visible in cross-polarized light microscopy, and the assemblage overlies those where $G$. oceanica is common, then it is likely that electron microscopy will confirm the presence of E. huxleyi. Gephyrocapsa protohuxleyi McIntyre (ranging from mid-Pleistocene to Holocene) has recently been indicated by McIntyre (1970) to be the progenitor of E. huxleyi. Electron microscopy is needed to clearly differentiate the two species.

\section{Gephyrocapsa oceanica Zone}

This zone is characterized by the abundance of Gephyrocapsa oceanica along with small forms of Ceratolithus cristatus, Cyclococcolithus leptoporus, Helicopontosphaera kamptneri, $H$. sellii, Gephyrocapsa aperta and $G$. protohuxleyi. The first common occurrence of Emiliania huxleyi can be used to distinguish the top of the zone. The bottom of the zone is marked by changes in the assemblage that include the earliest common occurrence of $G$. oceanica and the diminishing abundance of such species as Coccolithus doronicoides and Emiliania annula.

\section{Coccolithus doronicoides Zone}

This zone is characterized by an assemblage in which Coccolithus doronicoides, Cyclococcolithus leptoporus (small), and Emiliania annula are prominent. If present, Gephyrocapsa oceanica, Discoaster brouweri, Cyclococcolithus macintyrei and Ceratolithus rugosus are rare. A reduction in the abundance of $C$. doronicoides and $E$. annula indicate the top of the zone. The base is marked by the abrupt reduction in the abundance of $C$. macintyrei and $D$. brouweri. The replacement of $C$. rugosus by $C$. cristatus usually occurs near the base of this zone.

\section{Discoaster brouweri Zone}

Discoaster brouweri and Discoaster pentaradiatus are the dominant discoasters in the zone. The top of the zone is recognized by an abrupt reduction in the abundance of $D$. brouweri or D. pentaradiatus, Cyclococcolithus macintyrei, and Ceratolithus rugosus. The base of the zone is marked by the upper limit of Reticulofenestra pseudoumbilica, Sphenolithus abies and $S$. neoabies. In the upper part of the zone, three-rayed forms of $D$. brouweri may be especially frequent. In some areas it may be possible to subdivide this zone, on the basis of an earlier disappearance for $D$. pentaradiatus than for $D$. brouweri and $C$. macintyrei, into an upper C. Macintyrei Subzone and a lower $D$. pentaradiatus Subzone. Characteristic assemblages of this zone have mainly delicately rayed discoasters (M. N. Bramlette, personal communication, 1967) along with other forms such as those listed for Hole 62.1, Cores 6 and 7. 
TABLE 2

Approximate Correlation of Coccolith Zones Recognized in Sediment Recovered on Leg 7 in the Tropical Pacific to the Time-Stratigraphic Framework Recommended by the Deep Sea Drilling Project (Peterson and others, 1970). The Correlations Indicated Here are Based on Examination of Coccoliths from Type Sections (Bramlette and Wilcoxon, 1967; Bukry and Bramlette, 1968) and on Comparison of Planktonic Foraminifera and Coccolith Zones in Deep-Ocean Reference Sections (For Example, Gartner, 1969; Bukry and others, 1970).

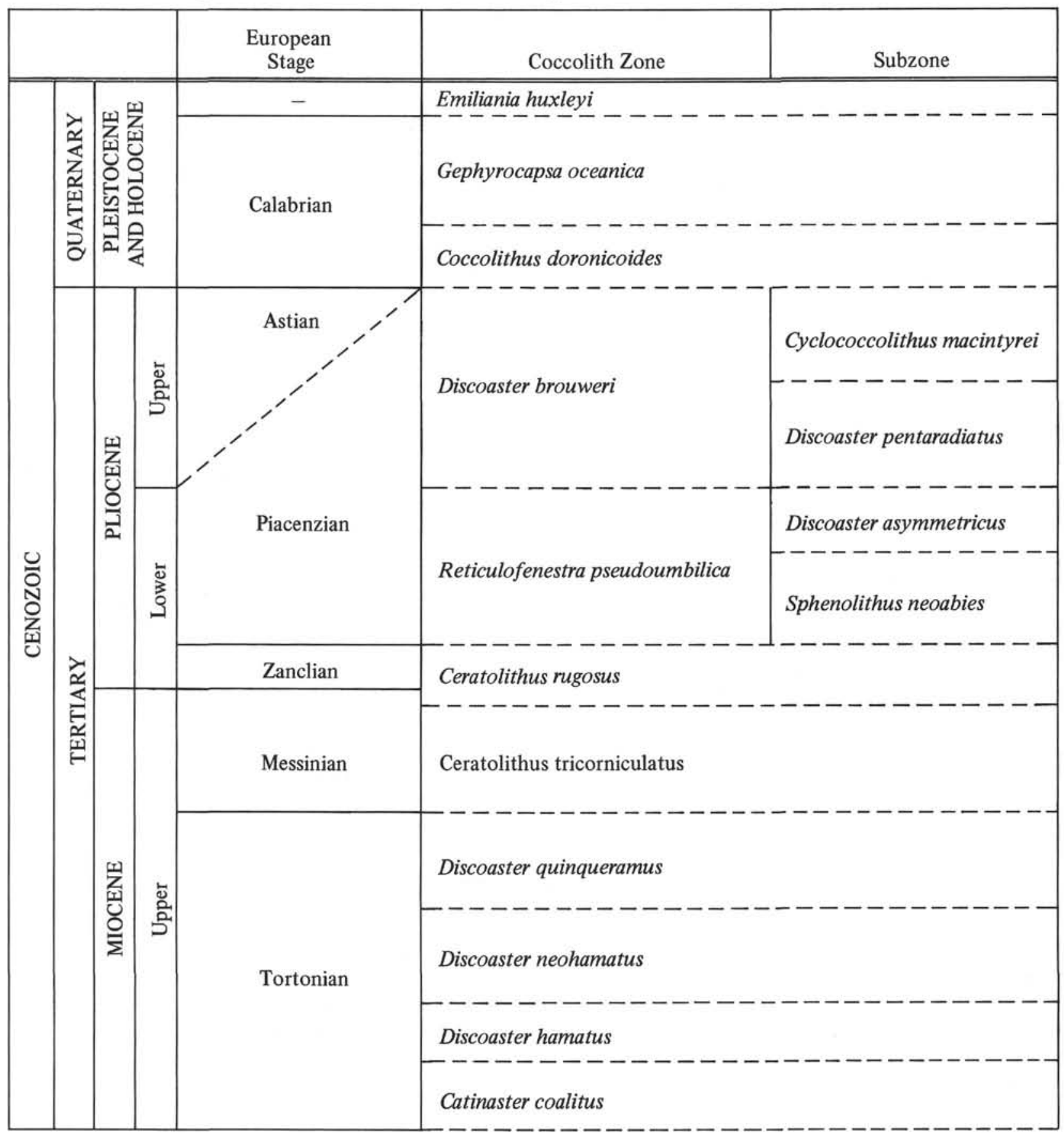


TABLE 2 - Continued

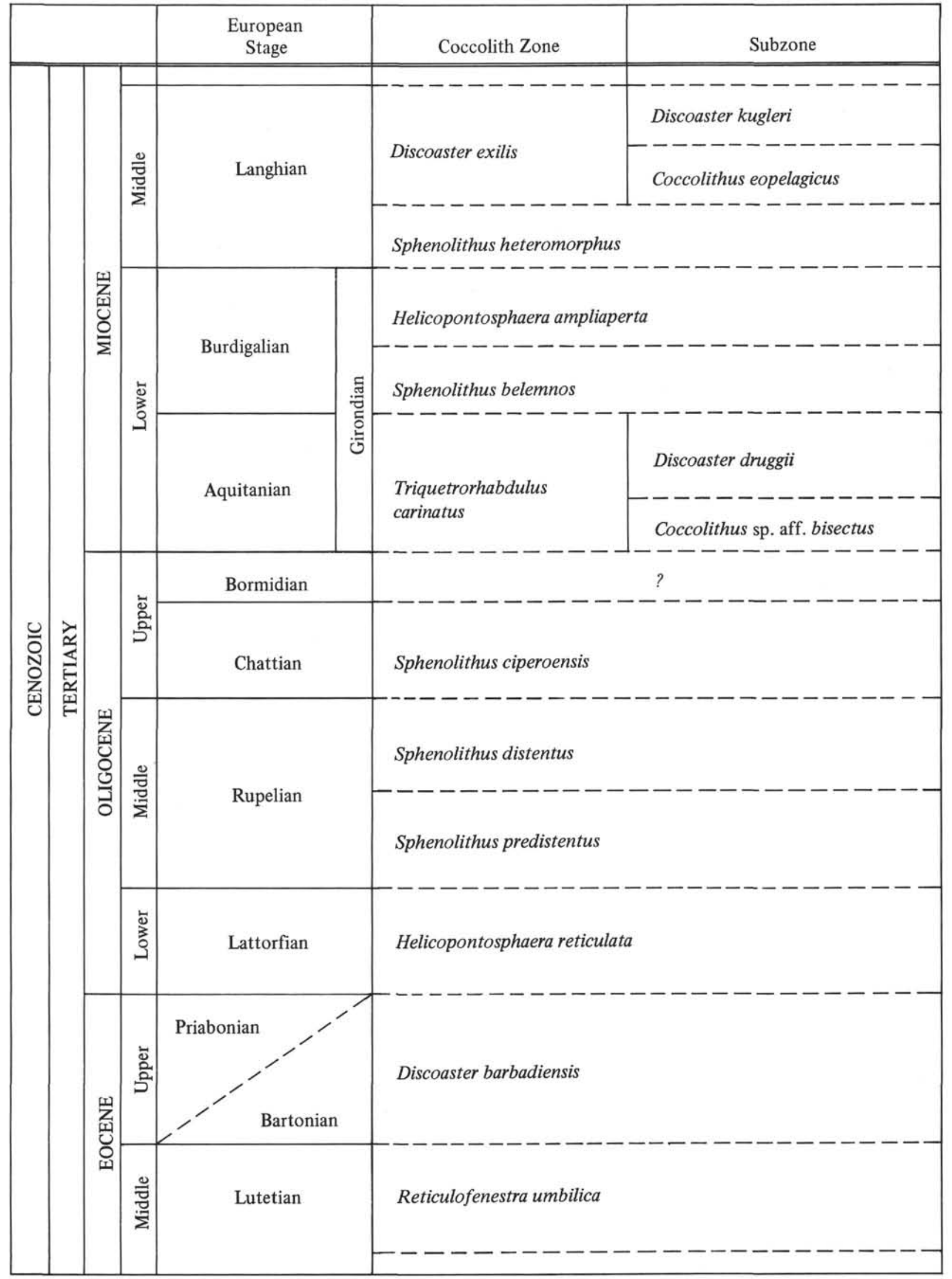




\section{Reticulofenestra pseudoumbilica Zone}

The top of the zone is marked by the extinctions of the common large form of Reticulofenestra pseudoumbilica, Sphenolithus abies, and $S$. neoabies. Discoaster challengeri rarely ranges above this zone as a natural occurrence. Common species within the zone include: Ceratolithus rugosus, Cyclococcolithus leptoporus, C. macintyrei, Discoaster brouweri, D. pentaradiatus, D. surculus, $R$. pseudoumbilica, $S$. abies and $S$. neoabies. Whereas the top of the zone is easily distinguished, the base is more difficult-the extinction of cosmopolitan Ceratolithus tricorniculatus and the earliest occurrences of Oolithotus antillarum being used for this determination. The occurrence of frequent Discoaster asymmetricus in the upper part of this zone may allow subdivision of the zone into an upper D. asymmetricus Subzone and lower $S$. neoabies Subzone.

\section{Ceratolithus rugosus Zone}

This interval can be variously recognized by the overlap in the ranges of Ceratolithus rugosus and C. tricorniculatus, the development of discoaster assemblages of fairly robust specimens of Discoaster surculus, D. pentaradiatus, $D$. challengeri and $D$. brouweri, and the rare presence or absence of Discoaster quinqueramus and Triquetrorhabdulus rugosus, which are generally consistent elements in the underlying $C$. tricorniculatus Zone. The overall assemblage is most similar to that of the $R$. pseudoumbilica Zone.

\section{Ceratolithus tricorniculatus Zone}

This zone is characterized by an assemblage containing: Ceratolithus tricorniculatus, Cyclococcolithus leptoporus, C. macintyrei, Discoaster brouweri, D. challengeri, D. pentaradiatus, D. quinqueramus [long-rayed variety], D. surculus, Reticulofenestra pseudoumbilica, Scyphosphaera sp. cf. S. apsteinii, Sphenolithus abies and Triquetrorhabdulus rugosus. The consistent presence of $D$. quinqueramus, $T$. rugosus and $C$. tricorniculatus in the absence of $C$. rugosus helps to distinguish this assemblage from that of the overlying $C$. rugosus Zone. The extinction of $T$. rugosus apparently occurs slightly lower than the first occurrence of $C$. rugosus and may serve to approximate the top of this zone in the absence of $C$. rugosus. The $C$. tricorniculatus Zone is distinguished from the underlying $D$. quinqueramus Zone by the presence of $C$. tricorniculatus, $S$. sp. cf. $S$. apsteinii, and by the common occurrence of $D$. pentaradiatus.

\section{Discoaster quinqueramus Zone}

The assemblages of this interval are characterized by the dominance of Discoaster brouweri, $D$. quinqueramus and $D$. surculus among the discoasters. The base of the zone is marked by the first occurrence of long-rayed forms of $D$. quinqueramus, the best development of short-rayed forms, and the last sparse occurrences of D. neohamatus. The top of the zone is indicated by the first occurrence of Creatolithus tricorniculatus and Scyphosphaera sp.cf. S. apsteinii and the increase in the abundance of $D$. pentaradiatus among the discoasters.

\section{Discoaster neohamatus Zone}

The common development of Discoaster neohamatus characterizes this interval between the extinction of $D$. hamatus and the appearance of common long-rayed $D$. quinqueramus. The assemblage of the interval includes Cyclococcolithus leptoporus, $C$. macintyrei, Discoaster brouweri, D. challengeri, D. neohamatus, Reticulofenestra pseudoumbilica, Triquetrorhabdulus rugosus, Sphenolithus abies, and, rarely, Discoaster pentaradiatus and $D$. surculus. Sparse $D$. quinqueramus, particularly the short-rayed variety, may be present in the upper part of this zone. The development of common $D$. brouweri Tan emended Bramlette and Riedel, 1954, within this zone in warm-water areas may result from gradual twisting of the rays of $D$. neohamatus (S. F. Percival, personal communication, 1969). Warm-water assemblages commonly contain an abundant, small fiverayed discoaster with simple tapering rays.

\section{Discoaster hamatus Zone}

The range of Discoaster hamatus is used to characterize this zone. Within this interval the overlap in the ranges of Catinaster calyculus and $C$. coalitus occurs. Association of $D$. hamatus and $C$. coalitus represent the lower part of the zone and $D$. hamatus and $C$. calyculus the upper part (M. N. Bramlette, personal communication, 1968). Discoaster neohamatus may occur in the upper part also. A typical assemblage also includes: Cyclococcolithus leptoporus, Discoaster brouweri s.l., D. challengeri, Reticulofenestra pseudoumbilica, Sphenolithus abies and Triquetrorhabdulus rugosus.

\section{Catinaster coalitus Zone}

Typically Catinaster coalitus specimens are common to abundant through this zone. The assemblage is similar to that of the overlying Discoaster hamatus Zone, and it is distinguished largely by the presence of $C$. coalitus in the absence of $D$. hamatus and Catinaster calyculus. The large species, Coccolithus eopelagicus, usually last occurs in assemblages of this zone.

\section{Discoaster exilis Zone}

This assemblage is characterized by the predominance of Discoaster exilis, D. challengeri, D. variabilis, and other long-rayed discoasters over $D$. deflandrei. Triquetrorhabdulus rugosus and Sphenolithus abies first occur as members of this assemblage. Sphenolithus heteromorphus, which characterizes the underlying zones, and Catinaster species that first occur in the overlying zones are convenient guides to distinguish the $D$. exilis assemblage, which includes Coccolithus eopelagicus, Cyclococcolithus leptoporus, C. macintyrei [small], Helicopontosphaera kamptneri, and Reticulofenestra 
pseudoumbilica. Within the $D$. exilis Zone, an upper subzone, the Discoaster kugleri Subzone, can be separated out on the basis of the first appearance of Discoaster kugleri, which apparently represents a final stage of the development of the Discoaster deflandrei group. The lower part of the $D$. exilis Zone may then be considered as the Coccolithus eopelagicus Subzone. Unless $D$. kugleri is identified, the assemblages are considered too similar to separate.

\section{Sphenolithus heteromorphus Zone}

The extinction of Sphenolithus heteromorphus marks the top of this zone (Triquetrorhabdulus rugosus generally appears only slightly higher and could be used to approximate the top of this zone where the cosmopolitan $S$. heteromorphus is absent). The base of the zone may be distinguished by the extinction of Helicopontosphaera ampliaperta and by a marked reduction of the frequency of Discoaster deflandrei among the discoasters with the first common appearance of longrayed discoasters. Ranges of the long-ranging Cyclococcolithus leptoporus and C. neogammation overlap in the zone. Reticulofenestra pseudoumbilica, a characteristically large coccolith of the upper miocene and lower Pliocene, has its first common occurrence in the lower part of this zone.

\section{Helicopontosphaera ampliaperta Zone}

Assemblages of this zone contain common to abundant Cyclococcolithus neogammation, Discoaster deflandrei and Sphenolithus heteromorphus. The top of the zone may be marked by the extinction of Helicopontosphaera ampliaperta, the first common occurrence of long-rayed discoasters, and by the earliest common occurrence of Reticulofenestra pseudoumbilica. The base of the zone may be recognized by the first appearance of $S$. heteromorphus and the disappearnce of S. belemnos.

\section{Sphenolithus belemnos Zone}

The top of this zone may be recognized by the last occurrence of Sphenolithus belemnos and the first occurrence of Sphenolithus heteromorphus. The base may be recognized by an increase in the abundance of $S$. belemnos. In the type area, this zone is characterized by an assemblage with common to abundant occurrence of Coccolithus eopelagicus, Cyclococcolithus neogammation, Discoaster deflandrei, Helicopontosphaera ampliaperta and $S$. belemnos. A few Orthorhabdus serratus and Triquetrorhabdulus carinatus [short form] are also present. Commonly, in deep ocean sediment this zone is only questionably identified owing to the general absence of $H$. ampliaperta and the sometimes sporadic occurrences of $T$. carinatus and $S$. belemnos. Thus this zone might become incorporated into the upper Triquetrorhabdulus carinatus Zone.

\section{Triquetrorhabdulus carinatus Zone}

The top of this zone is marked by the first common occurrence of Sphenolithus belemnos and a small variety of Helicopontosphaera ampliaperta. The base is marked by the last common occurrence of both Coccolithus bisectus and typical Sphenolithus ciperoensis. The earliest occurrence and presence of Discoaster druggii and Orthorhabdus serratus, together with a marked reduction in the abundance of Coccolithus sp. aff. C. bisectus, provides a useful basis for dividing this zone into an upper Discoaster druggii Subzone and lower Coccolithus sp. aff. C. bisectus Subzone in Pacific Ocean sediment.

\section{Sphenolithus ciperoensis Zone}

The extinction of Sphenolithus ciperoensis, Helicopontosphaera sp. aff. H. seminulum, and Coccolithus bisectus mark the top of this zone. The replacement of $C$. bisectus by $C$. sp. aff. C. bisectus within the zone is characteristic. The base is marked by the extinction of Sphenolithus distentus, Coccolithus sp. cf. C. scissurus, and the first occurrence of Triquetrorhabdulus carinatus.

\section{Spehnolithus distentus Zone}

The top of this zone is marked by the gradation of typical Sphenolithus distentus to Sphenolithus ciperoensis. The base is marked by the first occurrence of Coccolithus sp. aff. C. bisectus and Helicopontosphaera sp. aff. $H$. seminulum, as well as by the last occurrences of common Discoaster tani nodifer, Discoaster tani tani and Sphenolithus pseudoradians.

\section{Sphenolithus predistentus Zone}

The top of this zone is marked by the first occurrences of Helicopontosphaera truncata and Coccolithus sp. aff. C. bisectus and by the gradation of typical Sphenolithus predistentus to the succeeding Sphenolithus distentus. Other markers are the last occurrences of the Discoaster tani group and sparse Spehnolithus pseudoradians. The base of the zone is well marked by the last occurrences of several large coccolith species, such as, Cyclococcolithus formosus, Helicopontosphaera reticulata, Reticulofenestra umbilica, and the marked reduction of Helicopontosphaera compacta.

\section{Helicopontosphaera reticulata Zone}

The last occurrences of such large species as Cyclococcolithus formosus, Helicopontosphaera reticulata and Reticulofenestra umbilica mark the top of this zone. The base is marked by the last occurrence of Discoaster barbadiensis and $D$. saipanensis. Isthmolithus recurvus, which is most abundant near the top of the underlying zone, may be sparsely present in the lower part of this zone. $H$. reticulata is rarely noted as a member of the zonal assemblage in deep ocean sediment (Bukry and Bramlette, 1970). Assemblages of the zone are characterized by Bramletteius serraculoides, Coccolithus bisectus, C. sp. cf. C. scissurus, Cyclococcolithus formosus, 
C. neogammation, Discoaster deflandrei, D. tani nodifer, D. tani tani, Helicopontosphaera compacta, R. umbilica, Sphenolithus predistentus and $S$. pseudoradians.

\section{Discoaster barbadiensis Zone}

The top of this zone is marked by the extinction of Discoaster barbadiensis and $D$. saipanensis and by a marked reduction in the abundance of Isthmolithus recurvus. The base is marked by the extinction of Chiasmolithus grandis and by the first occurrence of large Discoaster tani tani. Bramletteius serraculoides, Coccolithus bisectus, C. sp. cf. C. scissurus, Cyclococcolithus formosus, D. barbadiensis, D. deflandrei, D. saipanensis, D. tani nodifer, D. tani tani and Reticulofenestra umbilica are cosmopolitan members of the zonal assemblage.

\section{Reticulofenestra umbilica Zone}

The top of this zone is marked by the first occurrence of large Discoaster tani tani and the last occurrence of Chiasmolithus grandis and Campylosphaera dela. The base is marked by the first occurrence of Reticulofenestra umbilica, which also approximates the extinction of Chiphragmalithus species.

\section{COCCOLITH STRATIGRAPHY OF CORES FROM LEG 7}

Sample numbers given under the biostratigraphic zones for each site represent, in the following sequence: leg number; drill-hole designation, consisting of site number plus a decimal suffix if more than one hole; core designation; core-section number; and, interval below the top of each core section in centimeters. For example, 7-62.1-32-2, 80-81 cm, indicates that the sample came from Leg 7, Hole 62.1 (at Site 62), the thirty-second barrel of core recovered, the second section from the top of that core, and from 80 to 81 centimeters below the top of the section. Core sections are 1.5 meters long, and most core runs were 9.1 meters long, but occasionally the core liners were not full. In this report, the tops of recoveries are arbitrarily placed at the top of the core runs, and an approximate depth in meters below the sea floor follows each sample number. A summary of zonal assignments of all cores examined is shown in Table 3.

HOLES 61.0 AND 61.1

(lat $12^{\circ} 05.0^{\prime} \mathrm{N}$., long $147^{\circ} 03.7^{\prime} \mathrm{E}$., depth 5562 meters)

No samples available. See results reported by shipboard scientists.

HOLES 62.0 AND 62.1

(lat $01^{\circ} 52.2^{\prime} \mathrm{N}$., long $141^{\circ} 56.0^{\prime} \mathrm{E}$., depth 2591 meters)

Summary of Coccolith Stratigraphy

The sediment at Site 62 was determined to be upper Tertiary mixed calcareous and siliceous ooze by spot cores from Hole 62.0, and was then continuously cored in Hole 62.1. Whereas Discoaster and Sphenolithus are especially abundant in the section, Ceratolithus is infrequent and sporadic. In general, coccolith assemblages are abundant and diverse and may be assigned to 20 zones and subzones from the Pleistocene Gephyrocapsa oceanica Zone to the lower Miocene Discoaster druggii Subzone. Two upper Miocene zones, not reported from outcrops on land, are particularly well-developed in these cores: the Discoaster quinqueramus Zone (Cores 20 to 25,193 to 242 meters) and the Discoaster neohamatus Zone (Cores 25 to 31,242 to 299 meters).

Pleistocene assemblages of the Gephyrocapsa oceanica Zone and Coccolithus doronicoides Zone are present to at least Core 4 (43 meters depth). Though no samples were available from Core 5 , the upper sample from Core 6 (55 meters) contains an assemblage of the upper Pliocene Cyclococcolithus macintyrei Subzone. Pliocene coccoliths of the Discoaster pentaradiatus Subzone, Discoaster asymmetricus Subzone and Sphenolithus neoabies Subzone are present through Core 13 (124 meters), where the top of the lower Pliocene or upper Miocene Ceratolithus rugosus Zone is recognized. The upper Miocene Ceratolithus tricorniculatus Zone is first recognized in Core 15 (146 meters): and, upper Miocene assemblages of the Discoaster quinqueramus Zone, Discoaster neohamatus Zone, Discoaster hamatus Zone and Catinaster coalitus Zone are present through Core 33 (314 meters). Middle Miocene zones are represented in the four succeeding cores of Hole 62.1 to a depth of 346 meters. Lower Miocene sediment assigned to the Helicopontosphaera ampliaperta Zone and the Discoaster druggii Subzone was sampled in Hole 62.0 at depths of 403 meters and 495 meters, respectively.

The discontinuous distribution of species, such as, Discoaster challengeri, Discoaster pentaradiatus, Discoaster surculus, Reticulofenestra pseudoumbilica and Triquetrorhabdulus rugosus in the upper Miocene Cores 22 to 29 (representing an expanded section) suggests possible short-term changes in the local environment, possibly stemming from relocation and shifting of Miocene oceanic currents.

Coccoliths in Selected Samples, Hole 62.0

$$
\begin{gathered}
\text { Lower Pliocene } \\
\text { (Reticulofenestra pseudoumbilica Zone, } \\
\text { Discoaster asymmetricus Subzone) }
\end{gathered}
$$

7-62.0-1-2, 103-105 cm (94 m):

Ceratolithus rugosus, Cyclococcolithus leptoporus, $C$. macintyrei, Discoaster asymmetricus, D. brouweri, $D$. challengeri, D. pentaradiatus, D. perplexus, Discolithina japonica, Helicopontosphaera kamptneri, H. sellii, Reticulofenestra pseudoumbilica, Scyphosphaera sp. cf. S. apsteinii, Sphenolithus neoabies.

7-62.0-1-5, 80-81 cm (98 m):

C. rugosus, C. leptoporus, D. asymmetricus, D. brouweri, D. challengeri, D. pentaradiatus, D. perplexus, $D$. 
TABLE 3

Zonal and Geologic Age Assignments of Cores from Leg 7 Holes

\begin{tabular}{|c|c|c|c|c|c|c|c|c|c|}
\hline \multirow{2}{*}{\multicolumn{2}{|c|}{ Zones }} & \multicolumn{8}{|c|}{ Holes } \\
\hline & & \multirow{2}{*}{62.0} & \multirow{2}{*}{62.1} & \multirow{2}{*}{63.0} & \multirow{2}{*}{63.1} & \multirow{2}{*}{63.2} & 64.0 & 64.1 & 65.0 \\
\hline 工罗至 & Emiliania huxley & & & & & & \multirow{2}{*}{1} & & \\
\hline 응 & Gephyrocapsa oceanica & & $1-2$ & 1 & & & & & \\
\hline 至荐 & Coccolithus doronicoides & & 4 & & \multirow{4}{*}{$1-3$} & 1 & & & \\
\hline \multirow{3}{*}{ 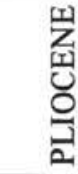 } & Discoaster brouweri & & $6-9$ & & & 2 & & & \\
\hline & Reticulofenestra pseudoumbilica & 1 & $10-13$ & & & 2 & 2 & & \\
\hline & Ceratolithus rugosus & & $13-15$ & & & $2-3$ & & & \\
\hline \multirow{10}{*}{ 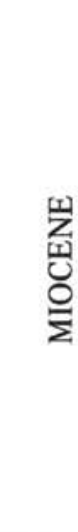 } & Ceratolithus tricorniculatus & & $15-20$ & & & & & & \\
\hline & Discoaster quinqueramus & 2 & $20-25$ & 2 & & & 3 & & \\
\hline & Discoaster neohamatus & & $25-31$ & & & & & & \\
\hline & Discoaster hamatus & 3 & $31-33$ & & 5 & & & & \\
\hline & Catinaster coalitus & & 33 & & 6 & & & & \\
\hline & Discoaster exilis & & $34-37$ & & $6-8$ & & & & \\
\hline & Sphenolithus heteromorphus & & & 3 & $8-13$ & & 5 & \multirow{2}{*}{$1-5$} & \\
\hline & Helicopontosphaera ampliaperta & 4 & & & & & & & \\
\hline & Sphenolithus belemnos & & & & & & & & \\
\hline & Triquetrorhabdulus carinatus & 5 & & $4-5$ & & & 6-7 & 6-7 & \\
\hline \multirow{4}{*}{ 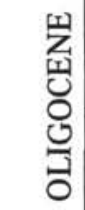 } & Sphenolithus ciperoensis & & & & & & 8 & 8 & \\
\hline & Sphenolithus distentus & & & 6 & & & & & \\
\hline & Sphenolithus predistentus & & & $6-9$ & & & 10 & & \\
\hline & Helicopontosphaera reticulata & & & & & & & & 14 \\
\hline \multirow{2}{*}{ 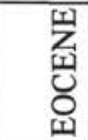 } & Discoaster barbadiensis & & & & & & & 9 & 14 \\
\hline & Reticulofenestra umbilica & & & & & & & 10 & \\
\hline
\end{tabular}


surculus, $H$. kamptneri, H. sellii, Oolithotus antillarum, $R$. pseudoumbilica, $S$. sp. cf. S. apsteinii, Sphenolithus abies, $S$. neoabies.

\section{Upper Miocene}

(Discoaster quinqueramus Zone)

7-62.0-2-6, 80-81 cm (213 m):

Coccolithus pelagicus, C. macintyrei, D. brouweri, D. pentaradiatus, $D$. quinqueramus, $D$. surculus, $H$. kamptneri, S. abies, Triquetrorhabdulus rugosus.

\section{Upper Miocene \\ (Discoaster hamatus Zone)}

7.62.0-3-6, 80-81 cm (307 m):

Catinaster sp. cf. C. calyculus, C. coalitus, C. pelagicus, C. leptoporus, D. brouweri s.l., D. challengeri, D. hamatus, $H$. kamptneri, $R$. pseudoumbilica, $T$. rugosus.

\section{Lower Miocene}

(Helicopontosphaera ampliaperta Zone)

7-62.0-4-6, 80-81 cm (403 m):

C. pelagicus, Cyclococcolithus neogammation, Discoaster deflandrei, D. perplexus, Sphenolithus heteromorphus, $S$. moriformis.

\section{Lower Miocene \\ (Triquetrorhabdulus carinatus Zone, Discoaster druggii Subzone)}

7-62.0-5-4, 80-81 cm (495 m):

Coccolithus sp. aff. C. bisectus, C. pelagicus, C. neogammation, $D$. deflandrei, $D$. sp. cf. $D$. druggii, $S$. moriformis, Triquetrorhabdulus carinatus.

\section{Coccoliths in Selected Samples, Hole 62.1}

Pleistocene

(Gephyrocapsa oceanica Zone)

7-62.1-1-3, 80-81 cm $(10 \mathrm{~m})$ :

Ceratolithus cristatus, Cyclococcolithus leptoporus, Gephyrocapsa oceanica, Helicopontosphaera sellii.

\section{Pleistocene}

(Coccolithus doronicoides Zone)

7-62.1-4-1, 80-81 cm (35 m):

C. cristatus, Coccolithus doronicoides, C. leptoporus, Emiliania annula, Helicopontosphaera kamptneri. Reworked Pliocene: rare Discoaster brouweri and $D$. pentaradiatus.

\section{Upper Pliocene}

(Discoaster brouweri Zone, Cyclococcolithus macintyrei Subzone)

7.62.1-6-1, 80-81 cm (55 m):

Ceratolithus rugosus, Coccolithus pelagicus, C. leptoporus, C. macintyrei, Discoaster asymmetricus, D. brouweri, D. perplexus, H. kamptneri.
Upper Pliocene

(Discoaster brouweri Zone, Discoaster pentaradiatus Subzone)

7-62.1-7-1, 80-81 cm (64 m):

$C$. rugosus, C. pelagicus, C. leptoporus, C. macintyrei, $D$. asymmetricus, $D$. brouweri, $D$. pentaradiatus, $D$. perplexus, D. surculus, $H$. kamptneri, $H$. sellii, Oolithotus antillarum, Scyphosphaera pulcherrima.

$7-62.1-8-6,80-81 \mathrm{~cm}(80 \mathrm{~m})$ :

C. rugosus, C. doronicoides, C. leptoporus, C. macintyrei, $D$. brouweri, D. pentaradiatus, $D$. surculus, $D$. variabilis, $H$. sellii.

7-62.1-9-4, 80-81 cm (86 m):

$C$. rugosus, $C$. leptoporus, C. macintyrei, D. asymmetricus, $D$. brouweri, $D$. pentaradiatus, $D$. perplexus, $D$. surculus, D. variabilis, $H$. sellii.

\section{Lower Pliocene \\ (Reticulofenestra pseudoumbilica Zone, Discoaster asymmetricus Subzone)}

7.62.1-10-1, 80-81 cm (93 m):

C. rugosus, $C$. leptoporus, $C$. macintyrei, D. asymmetricus [common], D. brouweri, D. challengeri, D. pentaradiatus, $H$. kamptneri, $H$. sellii, $O$. antillarum, Reticulofenestra pseudoumbilica, Scyphosphaera sp. cf. S. apsteinii, Sphenolithus abies.

\section{Lower Pliocene \\ (Reticulofenestra pseudoumbilica Zone, Sphenolithus neoabies Subzone)}

7-62.9-10-5, 80-81 cm (99 m):

$C$. rugosus, $C$. macintyrei, D. asymmetricus [rare], D. brouweri, D. challengeri, D. pentaradiatus, H. kamptneri, H. sellii, R. pseudoumbilica, Sphenolithus neoabies.

\section{Upper Miocene or Lower Pliocene (Ceratolithus rugosus Zone)}

7-62.1-13-4, 80-81 cm (124 m):

$C$. rugosus, $C$. tricorniculatus, $C$. leptoporus, $C$. macintyrei, D. brouweri, D. pentaradiatus, D. perplexus, $D$. surculus, H. kamptneri, $H$. sellii, $R$. pseudoumbilica, $S$. pulcherrima, $S$. abies.

7-62.1-15-4, 80-81 cm (143 m):

$C$. macintyrei, $D$. brouweri, $D$. challengeri, $D$. pentaradiatus, D. perplexus, D. surculus, H. kamptneri, R. pseudoumbilica, $S$. sp. cf. S. apsteinii, $S$. recurvata, S. abies.

\section{Upper Miocene}

(Ceratolithus tricorniculatus Zone)

7-62.1-15-6, 80-81 cm (146 m):

$C$. pelagicus, $C$. leptoporus, $C$. macintyrei, D. asymmetricus [rare], D. brouweri [rare], D. pentaradiatus, $D$. perplexus, D. surculus, H. kamptneri, H. sellii, R. pseudoumbilica, $S$. sp. cf. S. apsteinii, S. pulcherrima, $S$. abies, Triquetrorhabdulus rugosus [last common occurrence]. 
7.62.1-16-2, 80-81 cm (149 m):

D. quinqueramus [last common occurrence] .

7.62.1-16-4, 80-81 cm (152 m):

C. tricorniculatus [rare], C. leptoporus, C. macintyrei, $D$. brouweri, $D$. challengeri, $D$. quinqueramus [longrayed], D. surculus, $H$. kamptneri, $R$. pseudoumbilica, $S$. sp cf. $S$. apsteinii, $S$. abies, $S$. neoabies, T. rugosus.

7-62.1-20-4, 80-81 cm (191 m):

C. tricorniculatus [rare], C. leptoporus, C. macintyrei, $D$. brouweri [rare], D. quinqueramus, $D$. surculus, $H$. kamptneri, R. pseudoumbilica [small], S. abies, T. rugosus.

\section{Upper Miocene \\ (Discoaster quinqueramus Zone)}

7-62.1-20-5, 80-81 cm (193 m):

C. pelagicus, $C$. leptoporus, $D$. brouweri, D. perplexus, $D$. quinqueramus, D. surculus, $H$. kamptneri, S. abies, T. rugosus.

$7-62.1-24-4,80-81 \mathrm{~cm}(230 \mathrm{~m})$ :

C. pelagicus, $C$. leptoporus, D. brouweri, $D$. perplexus,

$D$. quinqueramus [short- and long-rayed], D. surculus,

H. kamptneri, S. abies, S. neoabies, T. rugosus.

\section{Upper Miocene \\ (Discoaster neohamatus Zone)}

7-62.1-25-6, 80-81 cm (242 m):

$C$. pelagicus, $C$. leptoporus, $C$. macintyrei, $D$. brouweri, $D$. challengeri, $D$. neohamatus, $D$. quinqueramus [shortrayed], $D$. sp. undescribed [small, five-rayed, no central knob, tapering and tilted rays], H. kamptneri, S. abies, $S$. neoabies, $T$. rugosus.

7-62.1-29-6, 80-81 cm (279 m):

C. pelagicus, C. leptoporus, C. macintyrei, $D$. challengeri, $D$. neohamatus, D. pentaradiatus, $R$. pseudoumbilica, S. abies, $S$. neoabies.

$7-62.1-31-5,80-81 \mathrm{~cm}(298 \mathrm{~m})$ :

C. pelagicus, $C$. leptoporus, C. macintyrei, D. brouweri s.l., D. challengeri, D. exilis, D. neohamatus, D. pentaradiatus, $H$. kamptneri, T. rugosus.

\section{Upper Miocene \\ (Discoaster hamatus Zone)}

7-62.1-31-6, 80-81 cm (299 m):

Catinaster calyculus, Coccolithus eopelagicus, C. pelagicus, C. macintyrei, D. brouweri s.l., D. calcaris, D. challengeri, D. hamatus, H. kamptneri, $R$. pseudoumbilica, T. rugosus.

7-62.1-33-2, 80-81 cm (312 m):

C. coalitus, C. pelagicus, C. macintyrei, D. brouweri s. $L$, $D$. hamatus [rare], D. sp. aff. D. variabilis, H. kamptneri, $R$. pseudoumbilica, $T$. rugosus.
Upper Miocene

(Catinaster coalitus Zone)

7-62.1-33-3, 80-81 cm (314 m):

C. coalitus, C. eopelagicus, C. pealgicus, C. macintyrei, $D$. brouweri s.l., $D$. challengeri, $D$. sp. aff. $D$. variabilis, H. kamptneri, $R$. pseudoumbilica, S. neoabies, $T$. rugosus.

\author{
Middle Miocene \\ (Discoaster exilis Zone, \\ Discoaster kugleri Subzone)
}

7-62.1-34-1, 80-81 cm (321 m);

$C$. eopelagicus, C. pelagicus, C. macintyrei, $D$. challengeri, D. perplexus, D. variabilis, $H$. kamptneri, $R$. pseudoumbilica, T. rugosus.

\author{
Middle Miocene \\ (Discoaster exilis Zone, \\ Discoaster kugleri Subzone)
}

7-62.1-35-4, 80-81 cm (332 m):

C. eopelagicus, C. pelagicus, C.leptoporus, C. macintyrei [small], D. brouweri s.l., D. exilis, D. kugleri, D. variabilis, $H$. kamptneri, $R$. pseudoumbilica, T. rugosus.

\section{Middle Miocene \\ (Discoaster exilis Zone, Coccolithus eopelagicus Subzone)}

7-62.1-36-2, $80-81 \mathrm{~cm}(338 \mathrm{~m})$ :

$C$. eopelagicus, $C$. macintyrei, $D$. challengeri, $D$. sp. cf. $D$. deflandrei, D. exilis, D. variabilis, $H$. kamptneri, $R$. pseudoumbilica, Scyphosphaera intermedia, T. rugosus.

7-62.1-37-2, 80-81 cm (346 m):

C. pelagicus, C. leptorporus, C. macintyrei [rare], $D$. deflandrei, D. exilis, H. kamptneri, R. pseudoumbilica, T. rugosus.

HOLES 63.0, 63.1 AND 63.2

(lat $0^{\circ} 50.2^{\prime} \mathrm{N}$., long $147^{\circ} 53.3^{\prime} \mathrm{E}$., depth $\mathbf{4 4 7 2}$ meters)

\section{Summary of Coccolith Stratigraphy}

Cores from Site 63, like those at Site 62, show a thick section of coccolith-rich sediment. The section extends from the Pleistocene Gephyrocapsa oceanica Zone near the surface to the middle Oligocene Sphenolith predistentus Zone at 558 meters.

In Core 3 of Hole 63.2, a ceratolith having the morphology of Ceratolithus tricorniculatus and crystallographic properties similar to Ceratolithus rugosus is present. This form may represent the link between these two species. Both species occur within the lower Pliocene or upper Miocene Ceratolithus rugosus Zone. 
Coccoliths in Selected Samples, Hole 63.0

Pleistocene

(Gephyrocapsa oceanica Zone)

7-63.0-1-6, 80-81 cm (8 m):

Ceratolithus cristatus, Cyclococcolithus leptoporus, Gephyrocapsa oceanica, Helicopontosphaera kamptneri.

\section{Upper Miocene \\ (Discoaster quinqueramus Zone)}

7-63.0-2-2, 80-81 cm (63 m):

Coccolithus pataecus, C. pelagicus, C. leptoporus, $C$. macintyrei, Discoaster asymmetricus, D. brouweri, $D$. pentaradiatus, D. quinqueramus [long-rayed], D. surculus [some five-rayed, asymmetric specimens], D. variabilis, Reticulofenestra pseudoumbilica [small], Triquetrorhabdulus rugosus.

Middle Miocene

(Sphenolithus heteromorphus Zone)

7-63.0-3-1, 80-81 cm (138 m):

Coccolithus eopelagicus, C. leptoporus, C. neogammation, Discoaster sp. cf. D. aulakos, D. brouweri s.l., D. variabilis, Sphenolithus heteromorphus.

\section{Lower Miocene}

(Triquetrorhabdulus carinatus Zone, Coccolithus sp. aff. C. bisectus Subzone)

7-63.0-4-2, 80-81 cm (232 m):

Coccolithus sp. aff. C. bisectus, C. eopelagicus, C. pelagicus, C. neogammation, D. deflandrei, Sphenolithus sp. aff. $S$. belemnos, Triquetrorhabdulus carinatus.

Middle Oligocene

(Sphenolithus distentus Zone)

7-63.0-6-1, 79-80 cm (459 m):

$C$. sp. aff. C. bisectus, $C$. eopelagicus, $C$. pelagicus, $C$. neogammation, $D$. sp. cf. $D$. deflandrei, Sphenolithus distentus, $S$. moriformis.

Middle Oligocene

(Sphenolithus predistentus Zone)

7-63.0-6-6, 80-81 cm (466 m):

$C$. eopelagicus, $C$. pelagicus, $C$. neogammation, $D$. deflandrei, D. tani tani, S. distentus, S. predistentus.

7-63.0-9-4, 85-86 cm (558 m):

Coccolithus bisectus, C. sp. aff. C. bisectus, C. eopelagicus, $C$. neogammation, D. deflandrei, D. tani tani, Pontosphaera vadosa, Sphenolithus predistentus [common].

\section{Coccoliths in Selected Samples, Hole 63.1}

Pliocene or Pleistocene (? Zone)

7-63.1-1-4, 50-51 cm (8 m):

Ceratolithus sp. cf. C. rugosus, Cyclococcolithus leptoporus, Discoaster variabilis, Sphenolithus abies.

\section{Lower Pliocene \\ (?Reticulofenestra pseudoumbilica Zone)}

7-63.1-3-2, 80-81 cm (24 m):

Ceratolithus rugosus, C. leptoporus, C. macintyrei, Discoaster asymmetricus, $D$. brouweri, $D$. challengeri, $D$. pentaradiatus, D. surculus, D. variabilis, Reticulofenestra pseudoumbilica.

\section{Upper Miocene \\ (Discoaster hamatus Zone)}

7-63.1-5-1, 80-81 cm (102 m):

Catinaster calyculus, C. leptoporus, C. macintyrei, Discoaster bollii [rare], D. brouweri s.l., D. challengeri, D. hamatus, $D$. neohamatus, $D$. perclarus, $R$. pseudoumbilica, Triquetrorhabdulus rugosus.

7-63.1-6-1, 80-81 cm (111 m):

Catinaster coalitus, C. pelagicus, C. leptoporus, Discoaster exilis, $D$. hamatus, $R$. pseudoumbilica, T. rugosus.

\section{Upper Mocene \\ (Catinaster coalitus Zone)}

7-63.1-6-2, 80-81 cm (112 m):

C. coalitus, $C$. macintyrei, D. brouweri s.l., D. challengeri, D. exilis, R. pseudoumbilica, T. rugosus.

\section{Middle Miocene \\ (Discoaster exilis Zone)}

7-63.1-6-6, 80-81 cm (118 m):

C. eopelagicus, C. macintyrei, D. brouweri s.l., D. challengeri, $D$. exilis, D. variabilis, $R$. pseudoumbilica, $T$. rugosus.

\section{Upper Miocene \\ (Discoaster hamatus Zone)}

7-63.1-8-2, 80-81 cm (131 m) [mislabeled?] :

C. coalitus, $C$. eopelagicus, $C$. pelagicus, $C$. macintyrei, $D$. challengeri, $D$. hamatus, D. variabilis, $R$. pseudoumbilica, $T$. rugosus.

\section{Middle Miocene \\ (Discoaster exilis Zone)}

7-63.1-8-5, 80-81 cm (136 m):

C. eopelagicus, $C$. pelagicus, C. leptoporus, C. macintyrei, Discoaster deflandrei, D. variabilis, $R$. pseudoumbilica [small], T. rugosus.

\section{Middle Miocene \\ (Sphenolithus heteromorphus Zone)}

7-63.1-8-6, 80-81 cm (137 m):

$C$. eopelagicus, $D$. deflandrei, $D$. variabilis, $R$. pseudoumbilica, Sphenolithus heteromorphus.

7-63.1-13-6, $72-73 \mathrm{~cm}(182 \mathrm{~m})$ :

C. eopelagicus, $C$. macintyrei [small], C. neogammation [abundant], D. deflandrei, D. sp. cf. D. druggii, D. exilis, S. heteromorphus. 
Coccoliths in Selected Samples, Hole 63.2

Pleistocene

(Coccolithus doronicoides Zone)

7-63.2-1-4, 80-81 cm (16 m):

Ceratolithus cristatus, C. rugosus, Coccolithus doronicoides, C. pelagicus, Cyclococcolithus leptoporus, Discoaster brouweri [rare], Emiliania annula, Gephyrocapsa caribbeanica, Helicopontosphaera kamptneri.

\section{Upper Pliocene}

(Discoaster brouweri Zone, Cyclococcolithus macintyrei Subzone)

7-63.2-2-1, 80-81 cm (21 m):

C. rugosus, C. pelagicus, C. leptoporus, C. macintyrei, $D$. brouweri [abundant], D. pentaradiatus [rare, $<1$ per cent], H. kamptneri. Oligocene or lower Miocene contamination: Cyclococcolithus neogammation, Discoaster deflandrei.

7-63.2-2-2, 80-81 cm (22 m):

C. rugosus, C. leptoporus, C. macintyrei, Discoaster asymmetricus, $D$. brouweri [abundant], D. pentaradiatus [rare], D. surculus [rare], H. kamptneri.

Lower Pliocene

(Reticulofenestra pseudoumbilica Zone)

7-63.2-2-3, 80-81 cm (24 m):

$C$. rugosus, $C$. leptoporus, $C$. macintyrei, $D$. asymmetricus, $D$. brouweri, $D$. pentaradiatus, $D$. surculus, $D$. variabilis, Reticulofenestra pseudoumbilica, Sphenolithus abies, S. neoabies.

\section{Lower Pliocene}

(Ceratolithus rugosus Zone)

7-63.2-2-4, 80-81 cm (25 m):

$C$. rugosus, $C$. sp. aff. $C$. tricorniculatus, $C$. macintyrei, Discoaster brouweri rutellus, $D$. challengeri, $D$. pentaradiatus, $H$. kamptneri, $R$. pseudoumbilica, S. abies.

7-63.2-3-4, 80-81 cm (35 m):

$C$. sp. aff. C. tricorniculatus, C. pelagicus, $C$. macintyrei, $D$. asymmetricus [rare], D. brouweri, $D$. challengeri, $D$. exilis, $D$. pentaradiatus, $D$. surculus, $D$. variabilis, $H$. kamptneri, H. sellii, R. pseudoumbilica [small], Scyphosphaera sp. cf. $S$. apsteinii, $S$. abies, $S$. neoabies.

\section{HOLES 64.0 AND 64.1 \\ (lat $01^{\circ} 44.5^{\prime} \mathrm{S}$., long $158^{\circ} 26.5^{\prime} \mathrm{E}$., depth 2052 meters)}

\section{Summary of Coccolith Stratigraphy}

Cores from Site 64 range from the Emiliania huxleyi Zone or Gephyrocapsa oceanica Zone at the surface to the Reticulofenestra umbilica Zone of the upper middle Eocene at 971 meters below the sea floor. Preservation in the middle Miocene to upper Eocene section (417 to 971 meters) is poor to average. Though rarely recorded from open-ocean deposits, Cyclococcolithus reticulatus is especially abundant in Core 9 of Hole 64.1, suggesting the possibility of relatively shallow deposition of the Eocene sediment here.

\section{Coccoliths in Selected Samples, Hole 64.0}

Pleistocene or Holocene

(Gephyrocapsa oceanica Zone or Emiliania huxleyi Zone)

7-64.0-1-1, 80-81 cm (1 m):

Ceratolithus cristatus, Cyclococcolithus leptoporus, Gephyrocapsa oceanica, Helicopontosphaera sellii.

Lower Pliocene

(Reticulofenestra pseudoumbilica Zone)

7-64.0-2-1, 80-81 cm (100 m):

Ceratolithus rugosus, C. leptoporus, C. macintyrei, Discoaster asymmetricus, $D$. brouweri, $D$. challengeri, $D$. exilis, $D$. pentaradiatus, $D$. perplexus, $D$. variabilis, Helicopontosphaera kamptneri, Oolithotus antillarum, Reticulofenestra pseudoumbilica, Scyphosphaera pulcherrima.

\section{Upper Miocene \\ (Discoaster quinqueramus Zone)}

7-64.0-3-1, 80-81 cm (203 m):

$C$. pelagicus, $C$. leptoporus, $C$. macintyrei, $D$. asymmetricus [rare], $D$. brouweri rutellus, $D$. pentaradiatus, $D$. quinqueramus, $D$. surculus, H. kamptneri, Sphenolithus abies, Triquetrorhabdulus rugosus.

Middle Miocene

(Sphenolithus heteromorphus Zone)

7-64.0-5-6, 80-81 cm (417 m):

C. pelagicus, $C$. leptoporus, $C$. neogammation, Discoaster deflandrei, $D$. exilis, $D$. variabilis, $R$. pseudoumbilica [small], Sphenolithus heteromorphus.

\section{Lower Miocene \\ (Triquetrorhabdulus carinatus Zone, Discoaster druggii Subzone)}

7-64.0-6-1, 80-81 cm (506 m):

Coccolithus sp. aff. C. bisectus, $C$. pelagicus, $C$. neogammation, $D$. deflandrei, $D$. sp. cf. $D$. druggii, Sphenolithus belemnos, Triquetrorhabdulus carinatus.

\section{Lower Miocene}

(Triquetrorhabdulus carinatus Zone)

7-64.0-7-6, 80-81 cm (618 m):

$C$. sp. aff. C. bisectus, C. eopelagicus, C. neogammation, $D$. deflandrei, Sphenolithus moriformis, T. carinatus.

\section{Upper Oligocene \\ (Sphenolithus ciperoensis Zone)}

7-64.0-8-3, 80-81 cm (709 m):

$C$. sp. aff. C. bisectus, $C$. pelagicus, $C$. eopelagicus, $C$. neogammation, $D$. deflandrei, Sphenolithus ciperoensis, $S$. moriformis [small], T. carinatus. 


\section{Middle Oligocene \\ (Sphenolithus predistentus Zone)}

7-64.0-10-1, 80-81 cm $(849 \mathrm{~m})$ :

Coccolithus bisectus, C. neogammation, D. deflandrei, $D$. tani tani, S. moriformis, $S$. predistentus.

Coccoliths in Selected Samples, Hole 64.1

Middle Miocene

(Sphenolithus heteromorphus Zone)

7-64.1-1-1, 80-81 cm (434 m):

Coccolithus pelagicus, Cyclococcolithus neogammation, Discoaster deflandrei, D. variabilis, Sphenolithus heteromorphus.

7-64.1-2-6, 80-81 cm (450 m):

Coccolithus eopelagicus, $C$. neogammation, D. deflandrei, $D$. dilatus, $D$. variabilis, $S$. heteromorphus.

\section{Middle or Lower Miocene \\ (Sphenolithus heteromorphus Zone or Helicopontosphaera ampliaperta Zone)}

7-64.1-3-1, 80-81 cm (452 m):

C. pelagicus, C. neogammation, $D$. deflandrei, S. heteromorphus.

7-64.1-4-6, 80-81 cm (469 m):

$C$. eopelagicus, $C$. neogammation, $D$. deflandrei, $D$. sp. $\mathrm{cf}$. D. dilatus, Reticulofenestra pseudoumbilica [small], $S$. heteromorphus, Triquetrorhabdulus sp. cf. T. carinatus [short].

$7-64.1-5-6,80-81 \mathrm{~cm}(478 \mathrm{~m})$ :

C. eopelagicus, $C$. neogammation, D. deflandrei, S. heteromorphus,

\section{Lower Miocene}

(Triquetrorhabdulus carinatus Zone, Coccolithus sp. aff. C. bisectus Subzone)

7-64.1-6-1, 80-81 cm (566 m):

Coccolithus sp. aff. C. bisectus, C. pelagicus, C. neogammation, D. deflandrei, Sphenolithus sp. aff. S. belemnos, $T$. sp. cf. T. carinatus [short] .

7-64.1-7-4, 80-81 cm (666 m):

Same as above.

\section{Upper Oligocene \\ (Sphenolithus ciperoensis Zone)}

7-64.1-8-2, 80-81 cm (748 m):

C. sp. aff. C. bisectus, C. eopelagicus, C. neogammation, D. deflandrei, Sphenolithus ciperoensis.

\section{Upper Eocene \\ (Discoaster barbadiensis Zone)}

7.64.1-9-1, 80-81 cm (914 m):

Bramletteius serraculoides, Coccolithus sp. cf. C. pseudogammation, Cyclococcolithus formosus, Cyclococcolithus reticulatus [rare], Discoaster barbadiensis, D. tani tani, Reticulofenestra umbilica.
7-64.1-9-3, 80-81 cm (915 m):

B. serraculoides, C. eopelagicus, $C$. formosus, $C$. reticulatus [abundant], $D$. barbadiensis, $D$. saipanensis, $D$. tani tani, Helicopontosphaera compacta, Zygrhablithus crassus.

\section{Middle Eocene \\ (Reticulofenestra umbilica Zone)}

7-64.1-10-1, 80-81 cm (970 m):

Campylosphaera dela, Chiasmolithus grandis, Coccolithus bisectus [small], $C$. eopelagicus, $C$. formosus, $D$. barbadiensis, D. tani tani [small, rare], H. compacta, Leptodiscus larvalis, Sphenolithus predistentus, S. radians, Triquetrorhabdulus inversus.

7-64.1-10-2, 80-81 cm (971 m):

B. serraculoides, C. dela, C. grandis, C. bisectus [small], C. eopelagicus, C. sp. cf. C. pseudogammation, C. formosus, $C$. inversus, $D$. barbadiensis, $D$. tani nodifer, Sphenolithus pseudoradians.

HOLES 65.0 AND 65.1

(lat $04^{\circ} 21.2^{\prime} \mathrm{N}$., long $176^{\circ} 59.2^{\prime} \mathrm{E}$., depth 6130 meters)

\section{Summary of Coccolith Stratigraphy}

The three coccolith samples from Site 65 contain typical but not abundant assemblages of the lower Oligocene Helicopontosphaera reticulata Zone and the upper Eocene Discoaster barbadiensis Zone.

\section{Coccoliths in Selected Samples, Hole 65.0}

$$
\begin{gathered}
\text { Lower Oligocene } \\
\text { (Helicopontosphaera reticulata Zone) }
\end{gathered}
$$

7-65.0-14-4, 140-141 cm (125 m):

Bramletteius serraculoides, Coccolithus bisectus, C. eopelagicus, C. pelagicus, Cyclococcolithus formosus, Discoaster deflandrei, D. tani tani, Pontosphaera vadosa, Reticulofenestra umbilica, Sphenolithus moriformis [small], S. predistentus.

\section{Upper Eocene \\ (Discoaster barbadiensis Zone)}

7-65.0-14-5, 145-150 cm (126 m):

B. serraculoides, C. bisectus, C. eopelagicus, C. pelagicus, $C$. formosus, Discoaster barbadiensis, $D$. deflandrei, $D$. sp. cf. D. deflandrei, $D$. saipanensis [small], D. tani nodifer, $D$. tani tani, $P$. vadosa, $R$. umbilica, $S$. moriformis [small], S. predistentus.

7-65.0-14-6, 115-116 cm (128 m):

B. serraculoides, C. bisectus, C. eopelagicus, C. pelagicus, $C$. formosus, $D$. barbadiensis, $D$. sp. cf. $D$. deflandrei, $D$. tani nodifer, D. tani tani, Helicopontosphaera sp. $\mathrm{cf}$. $H$. compacta, R. umbilica, S. moriformis [small], $S$. predistentus. 
No samples were available from Hole 65.1. See results reported by shipboard scientists.

\section{HOLES 66.0 AND 66.1 \\ (lat $02^{\circ} 23.6^{\prime} \mathrm{N}$., long $166^{\circ} 07.3^{\prime} \mathrm{W}$., depth 5293 meters)}

No samples available. See results reported by shipboard scientists.

$$
\begin{gathered}
\text { HOLES } 67.0 \text { AND } 67.1 \\
\text { (lat } 24^{\circ} 22.5^{\prime} \mathrm{N} .{\text { long } 157^{\circ} 39.1^{\prime} \mathrm{W} .,}^{\text {depth } 4473 \text { meters) }}
\end{gathered}
$$

No samples available. See results reported by shipboard scientists.

\section{REFERENCES}

American Commission on Stratigraphic Nomenclature, 1961. Code of stratigraphic nomenclature. Am. Assoc. Petrol. Geol. Bull. 45 (5), 645.

Berggren, W. A., 1969. Rates of evolution in some Cenozoic planktonic foraminifera. Micropaleontology. 15 (3), 351.

Bramlette, M. N. and Bukry, D., 1968. Ranges of Tertiary nannoplankton. JOIDES Deep Sea Drilling Project, Core description manual, pt. 7, sec. 2, table 3a.

Bramlette, M. N. and Riedel, W. R., 1954. Stratigraphic value of discoasters and some other microfossils related to recent coccolithorphores. J. Paleontology. 28, 403.

Bramlette, M. N. and Sullivan, F. R., 1961. Coccolithophorids and related nannoplankton of the early Tertiary in California. Micropaleontology. 7 (4), 129.

Bramlette, M. N. and Wilcoxon, J. A., 1967. Middle Tertiary calcareous nannoplankton of the Cipero Section, Trinidad W. I. Tulane Studies Geology. 5, 93.
Bukry, D. and Bramlette, M. N., 1968. Stratigraphic significance of two genera of Tertiary calcareous nannofossils. Tulane Studies Geology. 6, 149.

Bukry, D. and Bramlette, M. N., 1970. Coccolith age determinations Leg 3, Deep Sea Drilling Project. In Maxwell, A. E. et al., 1970, Initial Reports of the Deep Sea Drilling Project Volume IIJ. Washington (U.S. Government Printing Office) 589.

Bukry, D., Douglas, R. G., Kling, S. A. and Krasheninnikov, V., 1970. Biostratigraphy of the northwestern Pacific Ocean. In Heezen, B. C. et al., 1970, Initial Reports of the Deep Sea Drilling Project Volume VI. Washington (U.S. Government Printing Office).

Gartner, S., Jr., 1969. Correlation of Neogene planktonic foraminifer and calcareous nannofossil zones. Gulf Coast Assoc. Geol. Soc. Trans. 19, 585.

Hay, W. W., Mohler, H., Roth, P. H., Schmidt, R. R. and Boudreaux, J. E., 1967. Calcareous nannoplankton zonation of the Cenozoic of the Gulf Coast and Caribbean-Antillean area, and transoceanic correlation. Gulf Coast Assoc. Geol. Soc. Trans. 17, 428.

Heirtzler, J. R., Dickson, G. O., Herron, E. M., Pitman, W. C. and LePichon, X., 1968. Marine magnetic anomalies, geomagnetic field reversals, and motions of the ocean floor and continents. J. Geophys. Res. $73(6), 2119$.

McIntyre, A., 1970. Gephyrocapsa protohuxleyi sp.n. a possible phyletic link and index fossil for the Pleistocene. Deep-Sea Research. 17, 187.

Peterson, M. N. A., Edgar, N. T., Cita, M., Gartner, S., Jr., Goll, R., Nigrini, C. and von der Borch, C., 1970. Time-stratigraphic framework. Initial Reports of the Deep Sea Drilling Project, Volume II. Washington (U.S. Government Printing Office) 480. 